\title{
Effects of Liraglutide, a Human Glucagon-Like Peptide-1 Analog, on Glucose/Lipid Metabolism, and Adipocytokines in Patients With Type 2 Diabetes
}

\author{
Hidekatsu Yanai ${ }^{\mathrm{a}}$ b, d, Hidetaka Hamasaki ${ }^{\mathrm{a}}$, Hiroki Adachi ${ }^{\mathrm{a}}$, Sumie Moriyama ${ }^{\mathrm{a}}$, Yuji Hirowatari ${ }^{\mathrm{c}}$
}

\section{Letter to the Editor:}

The glucagon-like peptide 1 (GLP-1), one of gastrointestinal hormones, stimulates insulin secretion from pancreatic ß-cells in a glucose-dependent manner. Recently, liraglutide, a human GLP-1 analog, has been introduced as therapeutic strategies for type 2 diabetes mellitus. Clinical studies have demonstrated reduction in blood glucose and body weight, improvements in pancreatic ß-cell function and a low risk for hypoglycemia with liraglutide $[1,2]$. Since diabetes is significantly associated with cardiovascular events, it is very important to understand effects of anti-diabetic drugs on other cardiovascular risk biomarkers. Therefore, we studied effects of liraglutide on glucose/lipid metabolism and adipocytokines in patients with type 2 diabetes.

Five patients ( 4 females and one male) with type 2 diabetes participated in this study. The mean \pm SD of age, body height, body weight, body mass index and hemoglobin A1c were $60.2 \pm 8.9$ years old, $156.1 \pm 5.4 \mathrm{~cm}, 71.6 \pm 15.6 \mathrm{~kg}$, $29.5 \pm 7.0 \mathrm{~kg} / \mathrm{m}^{2}$ and $9.1 \pm 2.1 \%$, respectively. We measured high-sensitivity C-reactive protein (hs-CRP), adiponectin, interleukin-6, and small dense low-density lipoprotein (sdLDL), oxidized LDL (ox-LDL) and cholesterol level in each lipoprotein fraction using the high-performance liquid chromatography (HPLC) method before and after the two weeks

Manuscript accepted for publication August 22, 2011

a Department of Internal Medicine, National Center for Global Health and Medicine, Kohnodai Hospital, Chiba 272-8516, Japan

${ }^{b}$ Clinical Research Center, National Center for Global Health and Medicine, Kohnodai Hospital, Chiba 272-8516, Japan

${ }^{\mathrm{c} B i o s c i e n c e ~ D i v i s i o n, ~ T o s o h ~ C o r p o r a t i o n, ~ K a n a g a w a, ~ J a p a n ~}$

${ }^{\mathrm{d}}$ Corresponding author: Hidekatsu Yanai, Department of Internal

Medicine, National Center for Global Health and Medicine, Kohnodai Hospital, 1-7-1 Kohnodai, Chiba 272-8516, Japan.

Email: dyanai@hospk.ncgm.go.jp

doi:10.4021/jem38w treatment using liraglutide $(0.3 \mathrm{mg}$ for one week and $0.6 \mathrm{mg}$ for one week) [3].

The data are presented in Figure 1. A statistical significant increase in serum fasting C-peptide levels was observed following two week treatment with liraglutide. However, fasting plasma glucose levels were elevated. Although statistical significances were not obtained compared with baseline, serum levels of total cholesterol (TC) and triglyceride (TG) tended to decrease. Liraglutide also tended to reduce TG-rich lipoproteins such as chylomicron, intermediate density-lipoprotein (IDL), very low density-lipoprotein (VLDL) and sd-LDL. Although statistical significances were not also obtained compared with baseline, serum adiponectin levels decreased, and interleukin-6 and hs-CRP levels increased. Further, serum ox-LDL increased following liraglutide treatment.

In the LEAD (Liraglutide Effect and Action in Diabetes) 4 study, serum C-peptide levels significantly increased, and serum levels of TC, TG, LDL-cholesterol (LDL-C), free fatty acids (FFA) significantly decreased following 26-week treatment with liraglutide [4]. Seino Y et al performed the 24-week, multicenter, double blind, randomized parallelgroup trial compared the efficacy and safety of liraglutide and glibenclamide monotherapy in Japanese subjects with type 2 diabetes [5]. Liraglutide significantly reduced serum FFA levels compared with glibenclamide, however, there were no significant differences in serum levels of TC, LDLC, VLDL-C, HDL-C and TG between the two groups. In our study, liraglutide significantly increased serum C-peptide levels compared with baseline, which supports the results of LEAD 4 study and our previous study and also suggests that two weeks is sufficient to increase serum C-peptide $[4,6]$. To our knowledge, our report is the first to study serum levels of IDLC, CM-C, sd-LDL following liraglutide treatment. Although statistical significant differences were not obtained compared with baseline, liraglutide tended to reduce TG, TG-rich lipoprotein, and sd-LDL. In the LEAD 4 and study by Seino $\mathrm{Y}$ et al, liraglutide significantly decreased serum FFA levels [4, 5]. Liraglutide has been reported to reduce postprandial glucagon levels by $20 \%$ [7]. Glucagon stimulates lipolysis in adipocytes and increase plasma FFA levels [8]. Reduction of glucagon-mediated increase in serum FFA 


\begin{tabular}{lcc}
\hline & before & $\begin{array}{c}\text { 2 weeks after the use } \\
\text { of liraglutide }\end{array}$ \\
\hline fasting plasma glucose $(\mathrm{mg} / \mathrm{dl})$ & $106.4 \pm 16.7$ & $130.8 \pm 23.4$ \\
serum fasting C-peptide $(\mathrm{ng} / \mathrm{ml})$ & $1.11 \pm 0.38$ & $2.10 \pm 0.91^{*}$ \\
serum total cholesterol $(\mathrm{mg} / \mathrm{dl})$ & $195.4 \pm 46.7$ & $181.8 \pm 32.5$ \\
serum triglyceride $(\mathrm{mg} / \mathrm{dl})$ & $227.0 \pm 134.2$ & $163.6 \pm 62.6$ \\
serum LDL-C $(\mathrm{mg} / \mathrm{dl})$ & $109.6 \pm 25.5$ & $108.1 \pm 31.8$ \\
serum HDL-C $(\mathrm{mg} / \mathrm{dl})$ & $40.4 \pm 2.8$ & $41.0 \pm 4.3$ \\
HPLC-CM-C $(\mathrm{mg} / \mathrm{dl})$ & $2.98 \pm 0.94$ & $2.62 \pm 0.75$ \\
HPLC-IDL-C $(\mathrm{mg} / \mathrm{dl})$ & $9.84 \pm 2.95$ & $8.82 \pm 2.13$ \\
HPLC-VLDL-C $(\mathrm{mg} / \mathrm{dl})$ & $27.3 \pm 22.7$ & $17.4 \pm 7.8$ \\
HPLC-LDL-C $(\mathrm{mg} / \mathrm{dl})$ & $119.0 \pm 23.8$ & $118.9 \pm 34.8$ \\
HPLC-HDL-C $(\mathrm{mg} / \mathrm{dl})$ & $36.4 \pm 5.3$ & $38.0 \pm 3.3$ \\
small dense LDL $(\mathrm{mg} / \mathrm{dl})$ & $39.1 \pm 30.0$ & $32.5 \pm 16.8$ \\
oxidized LDL $(\mathrm{U} / \mathrm{l})$ & $140.8 \pm 49.6$ & $149.0 \pm 82.7$ \\
adiponectin $(\mu \mathrm{g} / \mathrm{ml})$ & $11.2 \pm 10.8$ & $7.1 \pm 5.7$ \\
interleukin-6 $(\mathrm{pg} / \mathrm{ml})$ & $2.5 \pm 1.4$ & $2.7 \pm 1.8$ \\
high sensitivity CRP $(\mathrm{ng} / \mathrm{ml})$ & $1009.4 \pm 1099.1$ & $1621.0 \pm 2639.5$ \\
\hline
\end{tabular}

Presented values indicate mean \pm S.D., ${ }^{*} P<0.05$ vs. values before the use of liraglutide by Wilcoxon's signed ranked test. LDL-C, low-density lipoproteincholesterol; HDL, high-density lipoprotein; HPLC-CM-C, chylomicron-cholesterol measured by high-performance liquid chromatography (HPLC); IDL, intermediatedensity lipoprotein; VLDL, very low-density lipoprotein; sd-LDL, small dense LDL; CRP, C-reactive protein

Figure 1. Effects of liraglutide on glucose and lipid metabolism and adipocytokines.

may be one of the underlying mechanisms for liraglutidemediated amelioration in serum lipids profile.

Courreges JP et al also measured adipocytokines following 14 week liraglutide treatment [9]. There was a non-significant, but dose-dependent reduction in hs-CRP levels by liraglutide. There were no treatment effects on levels of adiponectin and interleukin- 6 with liraglutide. In the study by Seino $\mathrm{Y}$ et al, liraglutide significantly reduced hs-CRP levels [5]. In our study, there were no treatment effects on levels of adiponectin, interleukin-6 and hs-CRP with liraglutide. To understand the effects of liraglutide on adipocytokines clearly, further studies should be performed.

In conclusion, the present study showed that two week treatment with liraglutide significantly increased serum fasting C-peptide levels. To elucidate the effects of liraglutide on lipid metabolism, adipocytokines and chronic inflammations, further studies, preferably with larger numbers of subjects, will be needed.

\section{References}

1. Vilsboll T, Zdravkovic M, Le-Thi T, Krarup T, Schmitz O, Courreges JP, Verhoeven R, et al. Liraglutide, a longacting human glucagon-like peptide-1 analog, given as monotherapy significantly improves glycemic control and lowers body weight without risk of hypoglycemia in patients with type 2 diabetes. Diabetes Care. 2007;30(6):1608-1610.

2. Vilsboll T, Brock B, Perrild H, Levin K, Lervang HH, 
Kolendorf K, Krarup T, et al. Liraglutide, a once-daily human GLP-1 analogue, improves pancreatic B-cell function and arginine-stimulated insulin secretion during hyperglycaemia in patients with Type 2 diabetes mellitus. Diabet Med. 2008;25(2):152-156.

3. Hirowatari Y, Yoshida H, Kurosawa H, Doumitu KI, Tada N. Measurement of cholesterol of major serum lipoprotein classes by anion-exchange HPLC with perchlorate ion-containing eluent. J Lipid Res. 2003;44(7):14041412.

4. Zinman B, Gerich J, Buse JB, Lewin A, Schwartz S, Raskin P, Hale PM, et al. Efficacy and safety of the human glucagon-like peptide-1 analog liraglutide in combination with metformin and thiazolidinedione in patients with type 2 diabetes (LEAD-4 Met+TZD). Diabetes Care. 2009;32(7):1224-1230.

5. Seino Y, Rasmussen MF, Nishida T, Kaku K. Efficacy and safety of the once-daily human GLP-1 analogue, liraglutide, vs glibenclamide monotherapy in Japanese patients with type 2 diabetes. Curr Med Res Opin. 2010;26(5):1013-1022.

6. Yanai H, Yoshimi T, Honda R. Effective Switch From Twice-Daily Pre-Mixed Insulin 50/50 to Liraglutide to Achieve a Good Glycemic Control in Type 2 Diabetes. J Med Cases 2011;2(2):76-80.

7. Ryan GJ, Foster KT, Jobe LJ. Review of the therapeutic uses of liraglutide. Clin Ther. 2011;33(7):793-811.

8. Carlson MG, Snead WL, Campbell PJ. Regulation of free fatty acid metabolism by glucagon. J Clin Endocrinol Metab. 1993;77(1):11-15.

9. Courreges JP, Vilsboll T, Zdravkovic M, Le-Thi T, Krarup T, Schmitz O, Verhoeven R, et al. Beneficial effects of once-daily liraglutide, a human glucagon-like peptide-1 analogue, on cardiovascular risk biomarkers in patients with Type 2 diabetes. Diabet Med. 2008;25(9):11291131. 